\title{
Reproduction and summer mortality of blue mussels Mytilus edulis in the Magdalen Islands, southern Gulf of St. Lawrence
}

\author{
Bruno Myrand ${ }^{1,2, *}$, Helga Guderley ${ }^{1}$, John H. Himmelman ${ }^{1}$ \\ ${ }^{1}$ Département de biologie, Université Laval, Québec G1K 7P4, Canada \\ ${ }^{2}$ Ministère de l'Agriculture, des Pêcheries et de l'Alimentation du Québec, Direction de l'Innovation et des \\ Technologies, C. P. 658, Cap-aux-Meules, Québec G0B 1B0, Canada
}

\begin{abstract}
We examined the relationship of summer mortality to reproductive events for suspensioncultured mussels Mytilus edulis L. in the Magdalen Islands. Parameters associated with gametogenesis and spawning were followed along with the timing and intensity of mortality from mid-June to midSeptember 1991. For mussels maintained in a shallow lagoon (the usual mussel culture site), summer mortality began in late July as a major spawning event was ending and as summer temperatures peaked $\left(>20^{\circ} \mathrm{C}\right)$. Mussels from this group showed low energetic contents after spawning and during the period of highest mortality, glycogen content decreased rapidly and shell growth ceased. Thus, mussels weakened by a major spawning were at the same time submitted to stressful temperatures. Summer mortalities were observed until the end of the experimental period (mid-September) even though surviving mussels seemed to have improved their condition in late August (when glycogen content, tissue mass and shell length had increased). By mid-September approximately $65 \%$ of the mussels had been lost. In contrast, no summer mortality was observed for mussels from the same stock that were maintained at $16 \mathrm{~m}$ depth in the open sea. These mussels were exposed to lower temperatures and spawned less extensively than those in the lagoon. They had no major spawning in late July and were never completely empty of gametes. Our results suggest that suspension-cultured mussels in Magdalen Islands lagoons pay a high reproductive cost in terms of survival when a major spawning is completed during a period of stressful environmental conditions, such as high water temperatures.
\end{abstract}

KEY WORDS: Blue mussel - Mytilus edulis - Reproduction - Reproductive cost - Summer mortality

\section{INTRODUCTION}

Summer mortalities of blue mussels Mytilus edulis L. cultured in the Magdalen Islands (southern Gulf of St. Lawrence, eastern Canada) were first noted in 1975 (Poirier \& Myrand 1982) and have often occurred since then (Myrand 1991a, Myrand \& Gaudreault 1995). These mortalities have severely impeded the development of a local mussel industry as they can cause up to $80 \%$ losses at a time.

Summer mortalities of cultured blue mussels have also been reported at other locations on the Allantic

\footnotetext{
•E-mail: bruno.myrand@agr.gouv.qc.ca
}

and Pacific coasts of North America (Mallet \& Myrand 1995). The extent of mortalities can be highly variable for different mussel stocks, even in the same environments (Dickie et al. 1984, Mallet et al. 1987, 1990, Mallet \& Carver 1989, Myrand 1990, Sephton 1991, Fuentes et al. 1992, Myrand \& Gaudreault 1995). All of the latter studies indicate that the mortalities are better explained by genetic than by environmental factors, but why and when is a given stock more susceptible to summer mortality?

The greater susceptibility of a given stock to summer mortality may reside in its higher degree of homozygosity for deficiency in heterozygotes according to the Hardy-Weinberg equilibrium) and the accompanying decrease in performance. The lower 
performance of more homozygous bivalves is well documented at various metabolic, physiological and ecological (including survival) levels (Diehl \& Koehn 1985, Beaumont \& Zouros 1991, Borsa et al. 1992, Gosling 1992). One mussel stock from the Magdalen Islands has never been affected by summer mortality (Myrand \& Gaudreault 1995) and is more heterozygous (as indicated by polymorphic enzymes) than the more susceptible stocks (Tremblay et al. 1998b,c). Of the 2 stocks that have been studied most extensively in the Magdalen Islands, the susceptible stock has higher maintenance requirements than the resistant stock during certain periods of the summer (Tremblay et al. 1998c). This association between homozygosity and maintenance metabolism agrees with previous studies (see review in Hawkins \& Bayne 1992). Mussels with higher mainienance requirements should have less energy available for other energetic processes (Diehl et al. 1986, Hawkins et al. 1986, Koehn \& Bayne 1989, Hawkins \& Bayne 1992) and thus be more vulnerable to adverse conditions. This corroborates Peterson's (1980) report that susceptible stocks of mussels have higher maintenance metabolism than more resistant stocks.

The lower performance of more homozygous individuals is accentuated, and sometimes only noticeable, under stressful conditions (Gentili \& Beaumont 1988, Hawkins et al. 1989, Koehn \& Bay̧ne 1989, Scott \& Koehn 1990, Borsa et al. 1992, Hawkins \& Bayne 1992, Tremblay et al. 1998a). Thus, it seems that the vulnerability of a susceptible (more homozygous) stock will be increased when conditions are adverse. Several stress-related factors have been examined to explain summer mortality including pathogens, high temperature $\left(>20^{\circ} \mathrm{C}\right)$, food depletion, thermal sensitivity and reproduction (Myrand \& Gaudreault 1995, Tremblay et al. 1998a,c). Taken alone, none of these factors can explain the summer mortalities in cultivated mussels from the Magdalen Islands except reproduction. These mussels usually have multiple spawnings starting in June, and summer mortality may be related to a major spawning taking place in late July, just before the warmest period of the year (Myrand \& Gaudreault 1995, Tremblay et al. 1998c). High water temperature was commonly identified as a probable cause of mortalities acting in synergy with other factor(s) (Freeman \& Dickie 1979, Incze et al. 1980, Mallet 1991, Sephton 1991). Mussel growers on Prince Edward Island, southern Gulf of St. Lawrence, have also noted a possible link between a second or late (July) major spawning and summer mortality (Emmett 1988).

Two studies report data on the reproductive cycle of suspension-cultured blue mussels in relation to summer mortality, and arrive at contradictory conclusions. Emmett et al. (1987) showed that summer mortality of
1 yr old blue mussels on the Canadian west coast was probably related to a reproductive stress, whereas Mallet (1991) could not find a clear relationship between the 2 parameters for 2 yr old mussels from Atlantic Canada.

The present study examines the role of reproduction in the summer mortalities of cultivated mussels from the Magdalen Islands. Two yr old mussels from a susceptible stock were followed from mid-June to midSeptember to examine the relation of summer mortality to reproductive events. Parameters associated with gametogenesis and spawning were quantified, along with the timing and intensity of mortality, to evaluate if summer mortality could represent a reproductive cost in terms of survival (Bell 1980, Bayne 1984, Thompson 1991). Experimental mussels were placed in 2 environments, one at the usual cuiture site in a lagoon where mortalities often occur (stressful conditions are likely to develop), and the other in the open sea where stressful conditions are not likely to develop because of the cooler temperatures (Bower 1989, Jamieson 1989). The study was performed in the natural environment because of the difficulties of obtaining an undisturbed gametogenic cycle under laboratory conditions (Lubet 1976) and further because reproductive costs in the laboratory may not reflect those in nature (Landwer 1994). The experiment was conducted in 1991, 1992 and 1993, but we primarily focused on the 1991 data as no mortality occurred in 1992 and 1993.

\section{MATERIALS AND METHODS}

We studied mussels from Great Entry lagoon (Fig. 1) which have previously been subjected to frequent summer mortalities (Myrand 1991a, Myrand \& Gaudreault 1995). In mid-June 1991, 1992 and 1993 we removed 2 yr old mussels measuring 50 to $60 \mathrm{~mm}$ in shell length from commercial sleeves (see Mallet \& Myrand 1995 for details on mussel culture techniques). In 1991, mussels were detached by hand, while in 1992 and 1993 the byssus was cut with scissors. These mussels were likely sexually mature as reproductive maturity in Mytilus edulis is attained at about $50 \mathrm{~mm}$ (Rodhouse et al. 1986). Groups of 50 mussels were placed in $19 \mathrm{~mm}$ mesh plastic cages $(25 \mathrm{~cm}$ length $x$ $25 \mathrm{~cm}$ width $\times 11 \mathrm{~cm}$ height). This large mesh-size was chosen to reduce fouling. The remaining mussels in $1991(n=359)$ were measured to the nearest millimeter, and a sample of 46 individuals was used to measure dry mass, energetic components and reproductive condition (as described below) at the onset of the experiment.

After being held overnight in holding tanks supplied with running seawater, the cages were placed in the 


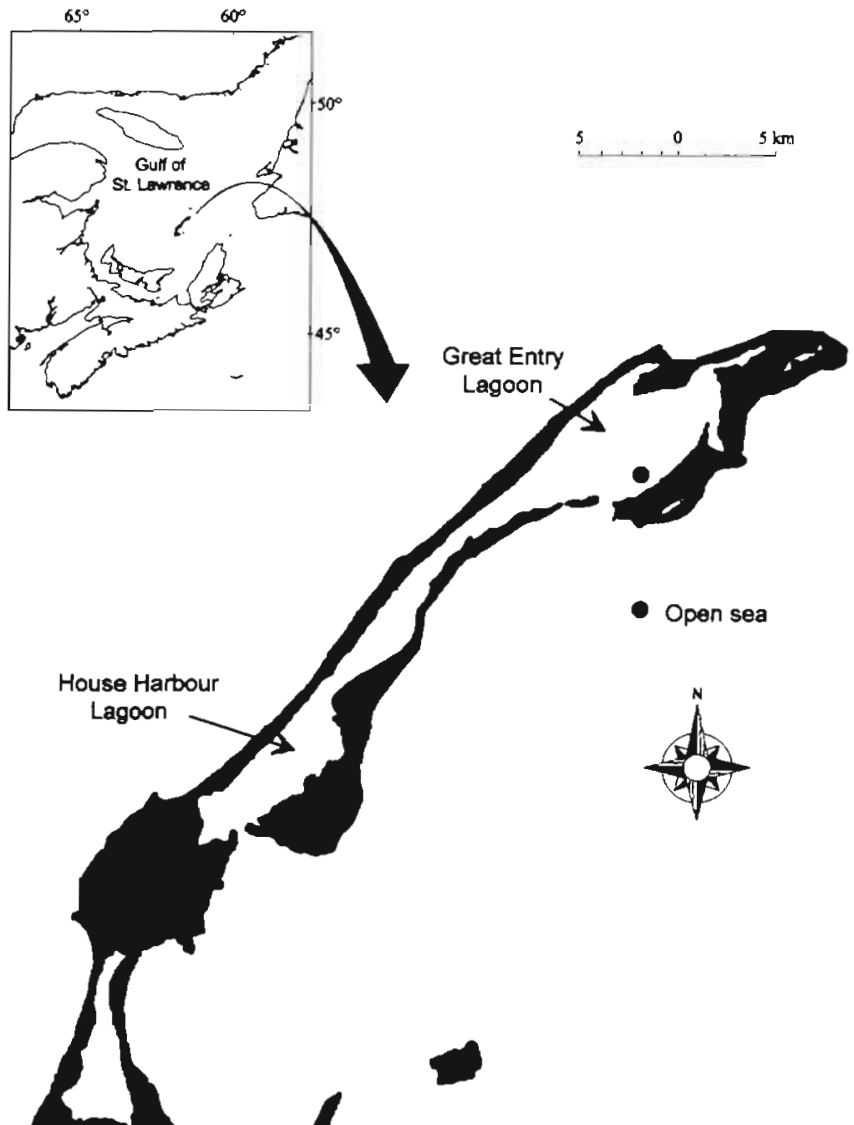

Fig. 1. Location of the 2 study sites in the Magdalen Islands

field, half in the Great Entry lagoon and half in the open sea (Fig. 1). The Great Entry lagoon is a shallow site ( $6 \mathrm{~m}$ deep) where environmental conditions (temperature, salinity, chlorophyll $a$ and seston) are well known (Myrand 1991b, Mayzaud et al. 1992). The open sea site was $16 \mathrm{~m}$ in depth and located $9 \mathrm{~km}$ from the shore. The cages were arranged in vertical series of 3 with adjacent cages separated by $30 \mathrm{~cm}$, and the 16 series of 3 cages at each site were distributed in a $4 \times 4$ matrix so that conditions were as uniform as possible. The deepest cage of each series in the open sea and in the lagoon was $2 \mathrm{~m}$ from the bottom. The distance between the series of cages was adjusted to avoid tangling and to facilitate retrieval of specific series (15 m in the lagoon and $30 \mathrm{~m}$ in the open sea). All cages were left undisturbed until they were retreived for sampling. Each year, a Ryan thermograph recorded temperatures at $2 \mathrm{~m}$ from the bottom near the experimental cages at both sites. However, the thermograph deployed at sea was lost in 1991.

At each sampling date, we randomly selected a series of 3 cages from each site. In 1991, we sampled weekly between mid-June and mid-September and twice weekly between 29 July and 22 August during the period when summer mortality was expected. In 1992 and 1993, we sampled weekly throughout summer.

In the laboratory, live and dead mussels from each cage were counted and measured to the nearest millimeter. Then all live mussels from the same site were mixed, and 46 individuals were sampled to measure dry mass, energetic components and reproductive condition as described below. Energetic components and reproductive condition were only determined in 1991 as no mortality occurred in 1992 and 1993. Mortality level in a given cage was calculated as (number of dead mussels/total number of mussels in the cage) $x$ 100 and, thus, represented the cumulative mortality from the onset of the experiment.

Mass determinations in 1991, 1992 and 1993. Thirty mussels from each sampling were frozen for later quantification of the dry mass of the mantle and viscera. Shell length was measured and tissues were dried at $65^{\circ} \mathrm{C}$ for $72 \mathrm{~h}$. Total dry mass was calculated as the sum of mantle and viscera masses.

Energetic components in 1991. To evaluate the energetic components, 6 mussels ( 3 males and 3 females) were measured, shucked and freeze-dried individually. We did not compare sexes because of the small number of mussels per sample. The equal number of males and females insured an equal weight of the 2 sexes in the determinations. The sex was identified from a biopsy of the mantle. Dry tissue mass was recorded before determinations of lipids (Bligh \& Dyer 1959), proteins (Kjeldahl method) and glycogen (Van Hendel 1965) were made using the analytical procedures detailed by Gendron \& Rioux (1994). The total energetic content of each mussel was estimated by summing the energetic equivalents for proteins $\left(23.65 \mathrm{~kJ} \mathrm{~g}^{-1}\right)$, carbohydrates $\left(17.16 \mathrm{~kJ} \mathrm{~g}^{-1}\right)$ and lipids $\left(39.55 \mathrm{~kJ} \mathrm{~g}^{-1}\right)$ as provided by Crisp (1984).

Reproductive condition in 1991. Ten mussels were shucked and fixed whole in a solution of $1 \% \mathrm{glu}$ taraldehyde: $4 \%$ formaldehyde for 24 h and then transferred to Davidson's fixative for storage (pers. comm., Dr Antonio J. Figueras, Instituto de Investigaciones Marinas CSIC, Vigo, Spain). Samples to be processed for histological studies were chosen to obtain more information on events suggested by changes in dry mass. For each mussel from the selected sampling dates, a piece of mantle was dissected and embedded in paraffin wax. Three $5 \mathrm{~mm}$ thick sections were cut through the piece of mantle at $120 \mathrm{~mm}$ intervals and stained with hematoxylin and eosin. The reproductive condition was assessed from 1 field per section ( 3 fields per mussel) using stereological analysis (Bayne et al. 1978, Lowe et al. 1982, Brousseau 1984). The propor- 
tion of gametes per field (gamete volume fraction, GVF) was derived from point counts obtained using a Weibel test grid applied on the PC screen of a Leica Q500MC image analysis system connected to the microscope (magnification: 100x). The 21 lines of the Weibel grid $(3 \times 7)$ were of equal length $(28 \mathrm{~mm})$, and the distance between the end points was $28 \mathrm{~mm}$ in every direction. This spacing of the end points was greater than the size of the gametes so that no more than 1 end point fell on a given gamete (Freere 1967. Briarty 1975). In the 3 sections of each female, we measured the diameter of the first 10 encountered oocytes sectioned through the nucleus (Grant \& Tyler 1983). As the oocytes are rarely perfectly round, the diameter was calculated as the mean of 4 measurements taken along 4 axis passing through the center of the nucleus ( 0 to $180^{\circ}, 45$ to $225^{\circ}, 90$ to $270^{\circ}$ and 135 to $315^{\circ}$ ). Oocytes with atretic (abnormal shape or color) or lytic (denaturated) characteristics were considered to be in resorption (Lubet 1959, Davidson \& Worms 1989).

The 10 mussels were selected regardless of their sex since numerous authors report no evidence of differences between sexes in gamete output, mantle mass, and the timing of gametogenesis and spawning (Lubet 1959, Griffiths \& Griffiths 1987, Hilbish \& Zimmerman 1988, Robledo et al. 1995, Salkeld 1995). However, factorial sex $\times$ site ANOVAs applied to arcsine-transformed GVF data for each sampling date indicated no significant interactions between sex and site (all p > $0.35)$ but differences between sexes on 2 dates (10 July: $F_{(1,19)}=10.08, \mathrm{p}=0.006 ; 28$ August: $F_{(1,18)}=10.23$, $p=0.006$ ). Therefore, the mean GVF was adjusted to give equal weight to both sexes.

Reproductive output in 1991. Reproductive output (fecundity) is often calculated as the difference between the dry mass of the mantle before and after spawning (Thompson 1979, Kautsky 1982, Bayne et al. 1983) as most gametes in mussels are located in the mantle (Seed \& Suchanek 1992, Salkeld 1995). However, since the mantle also contains energetic reserves (Seed \& Suchanek 1992), a better estimate of gamete biomass is obtained when mantle dry mass is adjusted for the proportion of the mantle occupied by gametes (Hilbish \& Zimmerman 1988). Thus, reproductive output was calculated as the difference in the mean dry mass of gametes (mean mantle dry mass $x$ mean adjusted GVF) in the mantle before and after spawning.

Environmental conditions in 1992 and 1993. In 1992 and 1993, weekly chl $a$ and seston concentrations were measured in triplicates at both sites in addition to daily temperature. Water samples were taken at $2 \mathrm{~m}$ from the bottom and filtered through a $135 \mathrm{~mm}$ mesh screen to remove zooplankton and large particles. In the laboratory, water was filtered under low vacuum pressure
( $<230 \mathrm{~mm} \mathrm{Hg}$ ) to prevent cell damage, and filters were stored at $-20^{\circ} \mathrm{C}$ until further analyses.

For chl a, $500 \mathrm{ml}$ water samples were filtered on Gelman GF/F filters and stored. Fluorescence was measured with a Turner fluorimeter after the filters had been transferred to vials containing $10 \mathrm{ml}$ of $90 \%$ acetone and refrigerated for $24 \mathrm{~h}$ at $5^{\circ} \mathrm{C}$. For seston, $2000 \mathrm{ml}$ water samples were filtered on pre-weighed and ashed $\left(450^{\circ} \mathrm{C}\right.$ for $\left.4 \mathrm{~h}\right)$ Gelman GF/C filters and then rinsed with $10 \mathrm{ml}$ of an isotonic solution (3\%) of ammonium formate to remove salts before storage. To quantify seston, filters were dried at $65^{\circ} \mathrm{C}$ for $24 \mathrm{~h}$ and then cooled in a dessicator at room temperature before being weighed again to the nearest 0.0001 g. Seston concentration was calculated as the difference between these 2 masses, and a correction factor was applied for mass loss during the filtration procedure.

Statistical analyses. All statistical analyses were performed using the 6.11 version of the program by SAS Institute (1982). When needed, data were transformed to obtain normality and homogeneity of variances. Dry masses and energetic components were $\log _{10}$ transformed and compared using ANCOVAs with $\log _{10}$ shell length as a covariable. Differences in mortality level and shell length throughout the summer were assessed using ANOVAs. Comparisons of means following the ANOVAs and ANCOVAs were performed using planned linear contrasts. Comparisons of mortality and shell length on successive dates were made using 1-tailed tests with planned linear contrasts to verify the hypothesis $H_{t+1}>H_{\mathrm{t}}$. Shell length distributions were not normally distributed and were compared using non-parametric Wilcoxon tests. The variance in the dry mass of gametes was calculated following Goodman's (1960) method since these values were the products of 2 distinct variables, gamete volume fraction and mantle dry mass.

\section{RESULTS}

We will mainly compare reproductive events and associated parameters for mussels in 1991 since this was the only year during which summer mortalities occurred.

\section{Spawning events}

At the beginning of the experiment on 12 June 1991, the mean mantle dry mass of mussels was $604 \mathrm{mg}$ (Fig. 2A) and represented $43.1 \%( \pm 0.9 \% \mathrm{SE}$ ) of total dry tissue mass. Although most individuals had follicles filled with gametes and a high GVF (58 to $67 \%$; 
Fig. 2B), 2 had a GVF of $<50 \%$, indicating that some spawning may have already taken place.

At both sites, spawnings of similar amplitude between 12 and 27 June 1991 were indicated by decreases in mantle mass (by $274 \mathrm{mg}$ in the lagoon and by $267 \mathrm{mg}$ in the open sea, Fig. 2A). These first spawnings only caused minor decreases in the GVF. On 27 June, the gametogenic stage was highly variable and the mean GVF was still high $157 \%$ in the lagoon and $52 \%$ at sea, Fig. 2B). The mass of gametes ex-
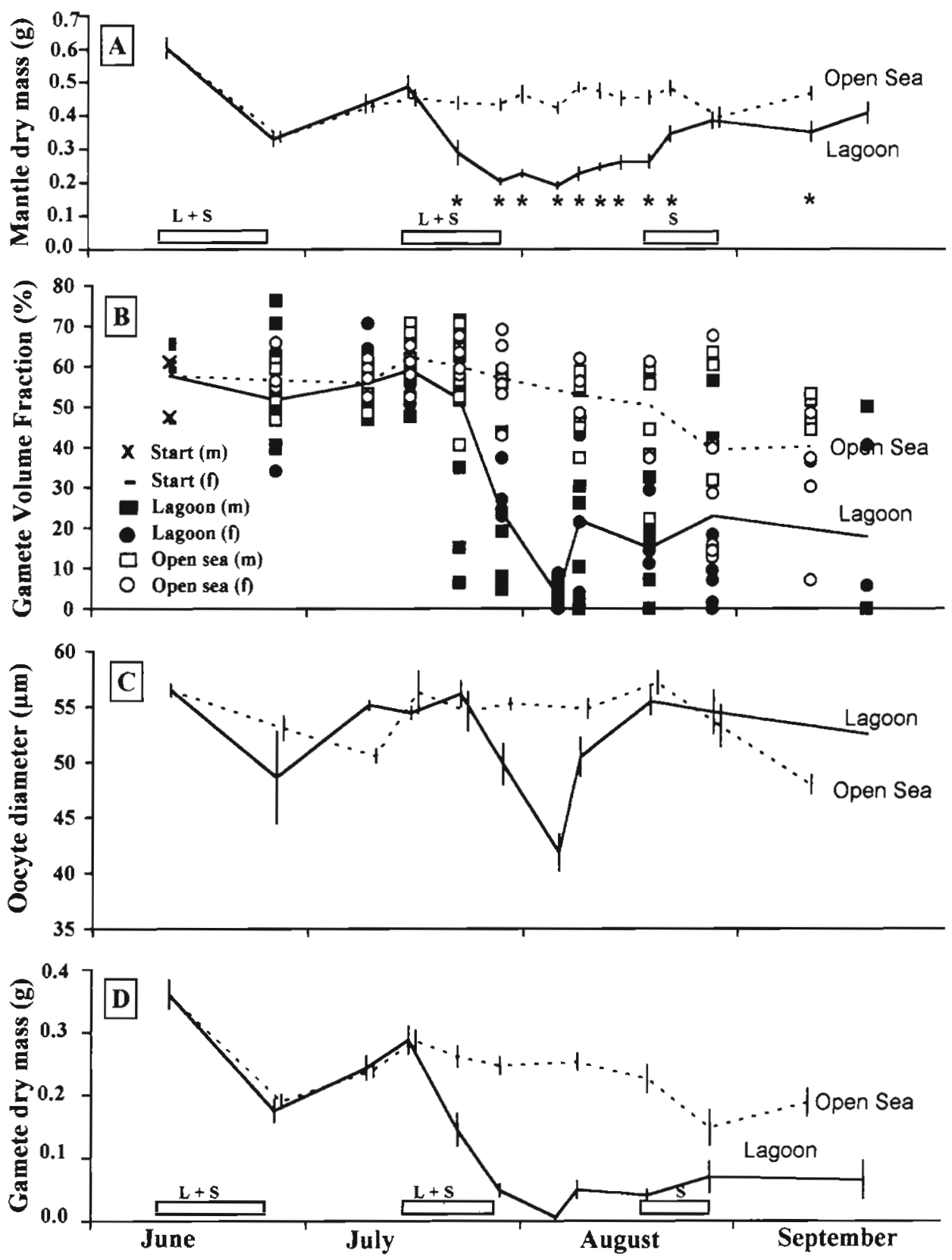

Fig. 2. Mytilus edulis. (A) Mean dry mass of mantle, (B) individual gamete volume fractions and mean values adjusted for an equal proportion of males and females, (C) mean size of oocytes, and (D) mean dry mass of gametes calculated as gamete volume fraction times mantle dry mass for mussels in the lagoon (-) and the open sea (---) in the Magdalen Islands between June and September 1991 Vertical bars represent standard errors. Periods of spawning in the lagoon (L) and in open sea (S) are indicated by the horizontal bars. Mantle dry mass was compared with an ANCOVA using shell length as the covariable, and planned linear contrasts were used to compare the 2 treatments (lagoon and open sea) at each date. Shell length and mantle mass were log 10 transformed before comparisons. Significant differences $(p<0.05)$ between sites are indicated by an asterisk 
pelled during these partial spawnings was estimated as $178 \mathrm{mg}$ in the lagoon and $158 \mathrm{mg}$ in the sea. At the end of these spawnings, mantle mass represented a sinilar proportion ( $t$-test: $t_{(29)}=1.30, p=0.49$ ) of total mass for the mussels in the lagoon $(34.0 \pm 0.7 \% \mathrm{SE})$ and open sea $(32.6 \pm 0.6 \% \mathrm{SE})$. Mean oocyte diameter decreased from an initial size of $56.5 \mu \mathrm{m}$ on 12 June to $48.6 \mu \mathrm{m}$ in the lagoon and $53.1 \mu \mathrm{m}$ at sea on $27 \mathrm{June}$ (Fig. 2C).

At both sites, similar increases in mantle mass occurred during the $3 \mathrm{wk}$ following the June spawning (Fig. 2A) and the mean GVF tended to increase slightly (Fig. 2B). However, after 16 July, mantle mass was usually higher for mussels at sea than in the lagoon (Fig. 2A; ANCOVAs for each date between 23 July and 11 September, except 28 August: $F_{(1,57)}=21.6$ to 251.5, $\mathrm{p}<0.0001$ ).

The mantle mass of the mussels at sea was relatively constant after 16 July (Fig. 2A) although the mean adjusted GVF decreased steadily (Fig. 2B). A few mussels had a GVF $<50 \%$ and lower mean oocyte diameters (Fig. 2C), suggesting that some individuals had a second spawning in late July. However, this was a small spawning as gamete dry mass only decreased by $37 \mathrm{mg}$ between 16 and 29 July (Fig. 2D). Another partial spawning occurred after 19 August as mantle mass and mean oocyte diameter decreased sharply and some mussels had low GVF values. The end of this spawning could not be defined precisely because of lost samples, but the stable mean GVF (Fig. 2B) and an increase in mantle mass (Fig. 2A) and gamete dry mass (Fig. 2C) suggested it was completed by 28 August. This latter spawning caused a 74 mg decrease in gamete dry mass and, when it was finished, mantle mass represented $33.2 \%( \pm 1.1 \% \mathrm{SE})$ of the total mass.

The mussels in the lagoon, in contrast those at sea, had a second major spawning between 16 and 29 July 1991 which resulted in a $284 \mathrm{mg}$ drop in mantle mass. This spawning was larger than that in June, as mantle mass dropped by $58 \%$ compared to $45 \%$ in June. When spawning was completed, mantle mass represented only $23.9 \%( \pm 0.7 \% \mathrm{SE})$ of the total mass. This spawning caused a $282 \mathrm{mg}$ decrease in gamete dry mass. On 6 August, all mussels in the lagoon were spent (GVF $<10 \%$ ) and the follicles contained only a few small $(41.9 \mu \mathrm{m})$ residual oocytes (Fig. 2B,C). The cumulative loss in gamete dry mass for the 2 spawnings in the lagoon was $460 \mathrm{mg}$. The low variance in mantle mass at the end of both spawnings in the lagoon (Fig. 2A) suggested that the entire experimental population had 2 successive and synchronous releases of gametes. Mantle mass increased again following the second spawning in the lagoon (Fig. 2A), and some individuals showed subsequent gamete development as indicated by increases in the GVF and mean oocyte diameter (Fig. 2B,C).

\section{Mortality}

Some mortality occurred soon after the beginning of the study in 1991 as dead mussels were found in the first sample on 27 June at both sites (Fig. 3A). In the open sea, no differences (ANOVA: $F_{(13,28)}=1.58, \mathrm{p}=$ 0.15 ) were observed in the proportion of dead mussels in cages on different sampling dates. In addition, the mean shell length of the dead mussels at sea throughout summer (54.2 $\mathrm{mm} \pm 0.2 \mathrm{~mm} \mathrm{SE} ; \mathbf{n}=383$ ) was almost the same as the initial shell length $(54.0 \mathrm{~mm} \pm 0.2 \mathrm{~mm}$ $\mathrm{SE}_{i} \mathrm{n}=359$ ). Also no differences were detected in shell length distributions (Wilcoxon test: $Z=-0.76 ; \mathrm{p}=0.45$ ). These observations suggested that most of the mortalities at sea occurred at the onset of the study. They were likely caused by the removal of the mussels from the sleeves. Thus, the mean mortality level of $18.9 \%$ ( $\pm 0.9 \% \mathrm{SE}$ ) for mussels at sea throughout summer likely represented a mortality caused by the initial manipulations

In contrast, mortality varied markedly (ANOVA: $\left.F_{(14,30)}=25.57, p<0.0001\right)$ during summer in the lagoon (Fig. 3A). The mortality at the 2 sites was compared for each date using linear contrasts as we found a significant site $\times$ date interaction (factorial ANOVA: $F_{(13,58)}=11.53$ for site $\times$ date interaction, $\left.p<0.0001\right)$. There were no significant differences between sites until 29 July ( $t \leq 1.55, p>0.09$ for all contrasts), except on 27 June $(t=2.40, \mathrm{p}=0.02)$. Thus, the mortalities observed in the lagoon during this period were probably the result of the initial manipulations. The mortality in the lagoon became significantly higher than that at sea from 1 August onwards $(t \geq 2.12, p<0.04$ for all contrasts; Fig. 3A). Therefore, a major summer mortality began between 29 July and 1 August and coincided with the end of the second major spawning (Fig. 2D). The mortality continued until the end of the study (mid-September) and was greatest in mid-August. Mussels which had recently died (still showing tissues attached to the shell) were first seen on 6 August and frequently thereafter. The estimated loss in the lagoon during the summer, excluding individuals which died after initial manipulations, was $65 \%$.

\section{Growth}

Mean shell length of mussels from both sites in 1991 was compared for each date using linear contrasts (Fig. 3B) as we observed a significant site $\times$ date interaction (Factorial ANOVA: $F_{(13,3027)}=3.16$ for site $\times$ date 
interaction, $\mathrm{p}<0.0001)$. At both sites, shell length was similar on 27 June $(t=0.75, \mathrm{p}=0.65)$ and 10 July $(t=1.32$, $p=0.19)$. Then, between 10 and 29 July shell length in the lagoon increased suddenly $\left(0.136 \mathrm{~mm} \mathrm{~d}^{-1}\right)$ even though this period coincided with the second major spawning (Fig. 3B). In contrast, mussels at sea only grew slightly as they were partially spawning in late July.
In 1991, shell growth in the lagoon ceased as the summer mortality began (between 29 July and 19 August) only to increase markedly between 19 and 28 August $\left(0.471 \mathrm{~mm} \mathrm{~d}^{-1}\right)$. This growth was not merely the consequence of selective mortality of smaller individuals as substantial growth occurred also at sea in the absence of mortality (Fig. 3B). Synchronous sharp
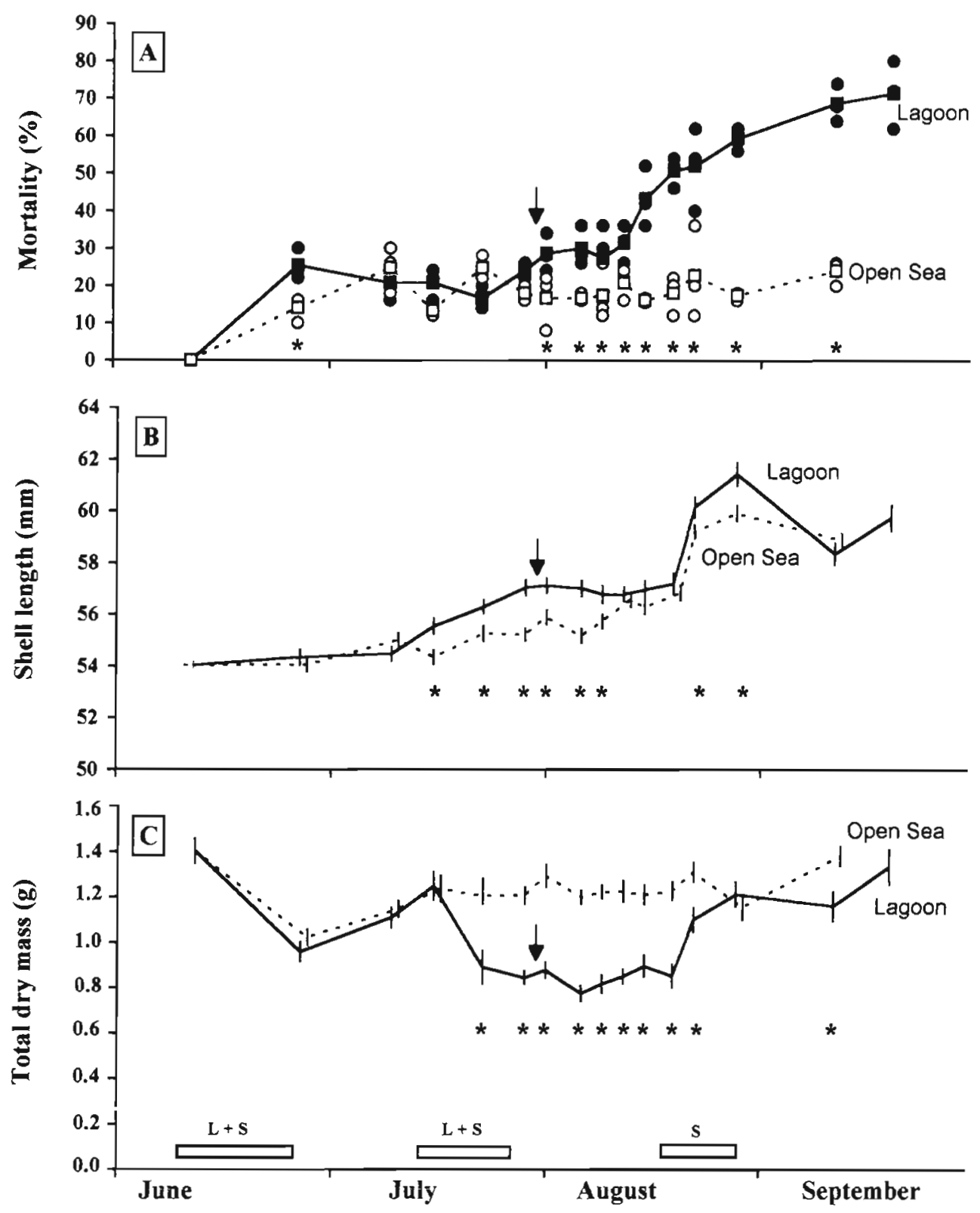

Fig. 3. Mytilus edulis. (A) Mortality in individual cages and mean values, (B) mean shell length of living individuals, and (C) mean total dry mass for mussels in the lagoon (-) and the open sea (-..) in the Magdalen Islands between June and September 1991. Vertical bars represent standard errors. Periods of spawning in the lagoon (L) and in open sea (S) are indicated by the horizontal bars. Mortality and shell length were compared using ANOVAs while total dry mass were compared with an ANCOVA applied to $\log _{10}$ transformed values using shell length as the covariable. In all cases, the 2 treatments (lagoon and open sea) at each date were compared using planned linear contrasts. Significant differences $(p<0.05)$ between sites are indicated by an asterisk. The arrowshows the onset of summer mortality 
increases in mantle mass, shell length and total mass suggested that surviving mussels in the lagoon were in good condition even though their numbers had been decimated by the summer mortality (Figs. 2A \& 3B,C). Mantle mass and total mass were highly correlated throughout the summer $(\mathrm{r}=0.92, \mathrm{p}<0.0001, \mathrm{n}=920$; Figs. 2A \& $3 \mathrm{C}$ ). Mussels at sea grew at a rate of
$0.341 \mathrm{~mm} \mathrm{~d}^{-1}$ in late August even though they were losing a portion of their total mass due to spawning (Fig. 3B,C). At both sites, the rapid growth in late August suggested a general improvement in environmental conditions. Nonetheless, $42 \%$ of the mussels that were alive on 19 August, when shell length began to increase sharply, were dead 1 mo later.
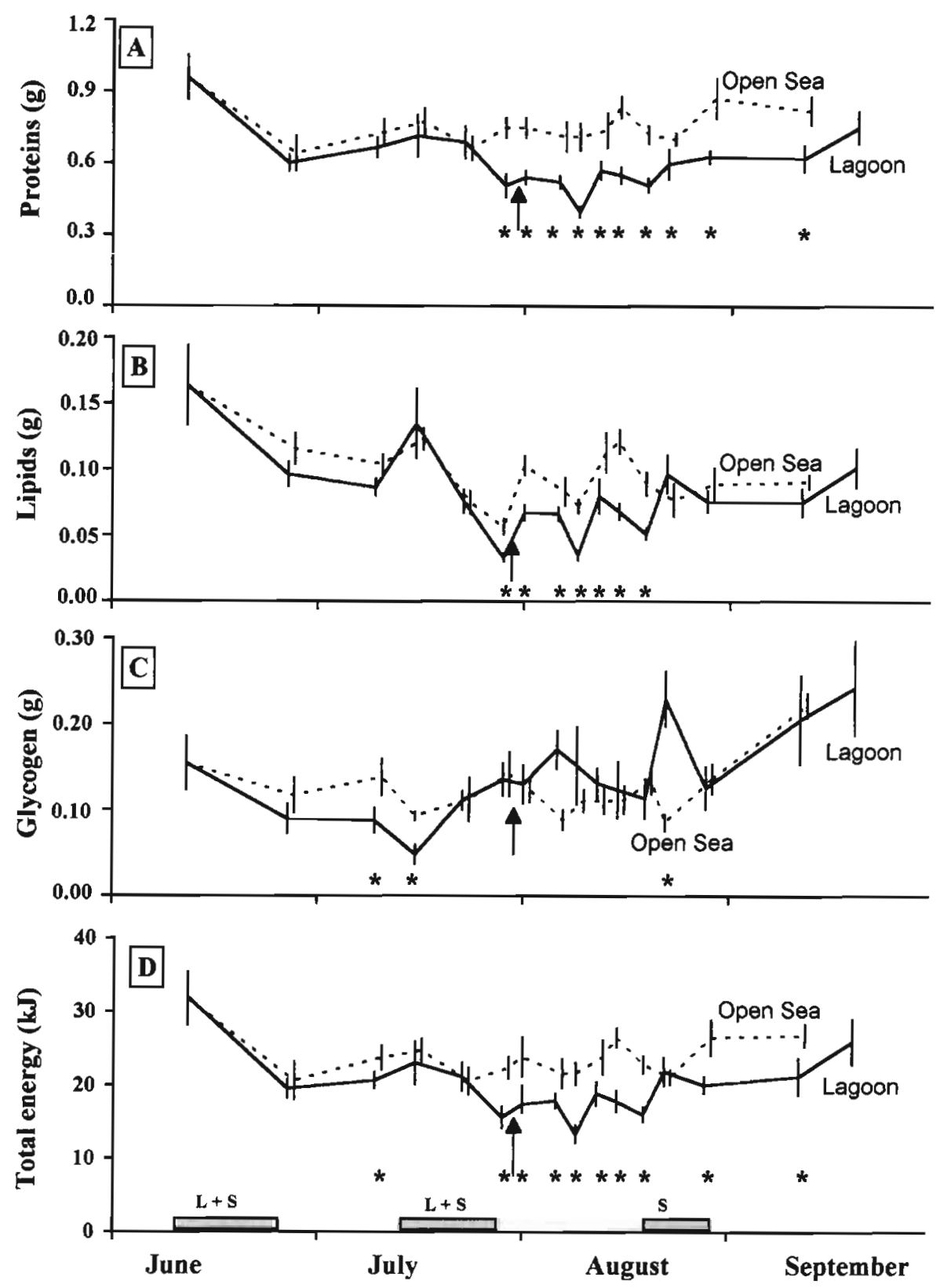

Fig. 4. Mytilus edulis. (A) Total protein, (B) lipid, (C) glycogen and (D) energy contents for mussels in the lagoon (- $\longrightarrow$ ) and the open sea (-..-) in the Magdalen Islands between June and September 1991. Vertical bars represent standard errors. Periods of spawning in the lagoon (L) and in open sea (S) are indicated by the horizontal bars. Comparisons were performed using ANCOVAs applied to $\log 10$ transformed values with shell length as the covariable, and planned linear contrasts compared the 2 treatments (lagoon and open sea) at each date. Significant differences ( $p<0.05$ ) between sites are shown by an asterisk. The arrow shows the onset of summer mortality 


\section{Energetic components}

To examine the overall trends in energetic components, we applied 2-way (site $\times$ sampling date) ANCOVAs using shell length as a covariable, to our data. As we observed significant interactions for all components (proteins: $F_{(13,157)}=3.29, \mathrm{p}=0.0002$; lipids: $F_{(13,155)}=$ 3.06, $\mathrm{p}=0.0005$; glycogen: $F_{(13,156)}=2.06, \mathrm{p}=0.02$; total energetic content: $\left.F_{(13,154)}=2.30, p=0.008\right)$, we used linear contrasts to compare the 2 sites for each sampling date in 1991 (Fig. 4A to D).

At both sites, all energetic components decreased during the first spawning in late June (Fig. 4A to D). Then, protein, lipid and total energetic content increased in mussels at the 2 sites until the beginning of the second spawning in mid-July, when gametes composed mainly of proteins and lipids started being released. Energetic components differed significantly between the 2 sites during the remainder of the summer, and values were notably higher at sea than in the lagoon between 29 July and 19 August. The same general pattern of temporal changes was observed when data were expressed as relative values $\left(\mathrm{mg} \mathrm{mg}^{-1}\right.$ dry mass) rather than as absolute values. However, except for protein content, differences between sites were less obvious when values were expressed as a percentage of total dry mass. This was probably because of the low proportion of glycogen (5 to $20 \%$ ) and lipids ( 4 to $14 \%$ ) relative to proteins ( 55 to $70 \%$ ) and other components ( 15 to $20 \%$ ). The lower values in late July in the lagoon confirmed the greater spawning activity at this site. At the end of the second spawning in the lagoon, total mass and total energetic content were at a minimum as a result of the major decreases in protein and lipid contents (gamete constituents) (Figs. 3C \& 4D).

After the initial decline in early summer, glycogen content varied inversely with the other components (Fig. 4C). That glycogen content did not increase after the first spawning in the lagoon suggested that no reserves had accumulated prior to the second spawning. Glycogen content fell to its lowest level on 16 July, the beginning of the second spawning, and then increased rapidly to the level observed in mid-June. The glycogen content decreased rapidly over the $2 \mathrm{wk}$ period ( 6 to 19 August) when growth ceased (Fig. 3B) and summer mortality peaked (Fig. 3A). The glycogen increase after late August coincided with increases in total mass and shell length, further suggesting a general improvement in the condition of the mussels in the lagoon.

\section{Experiments in 1992 and 1993}

There were no summer mortalities observed during the monitoring of the same stock maintained at the same 2 sites in 1992 and 1993. The cumulative mortality in the lagoon and open sea was $6.8 \%( \pm 3.5 \%$ $\mathrm{SE})$ and $6.1 \%( \pm 2.0 \% \mathrm{SE})$, respectively, in mid-September 1992 and $6.8 \%( \pm 3.1 \% \mathrm{SE})$ and $2.0 \%( \pm 1.2 \%$ $\mathrm{SE})$, respectively, in late September 1993. In these years, mantle mass never decreased as far as in the lagoon in 1991 (Figs. 2A \& 5), suggesting that the spawnings were not complete. Further the follicles were partly filled with gametes at the end of each spawning event.
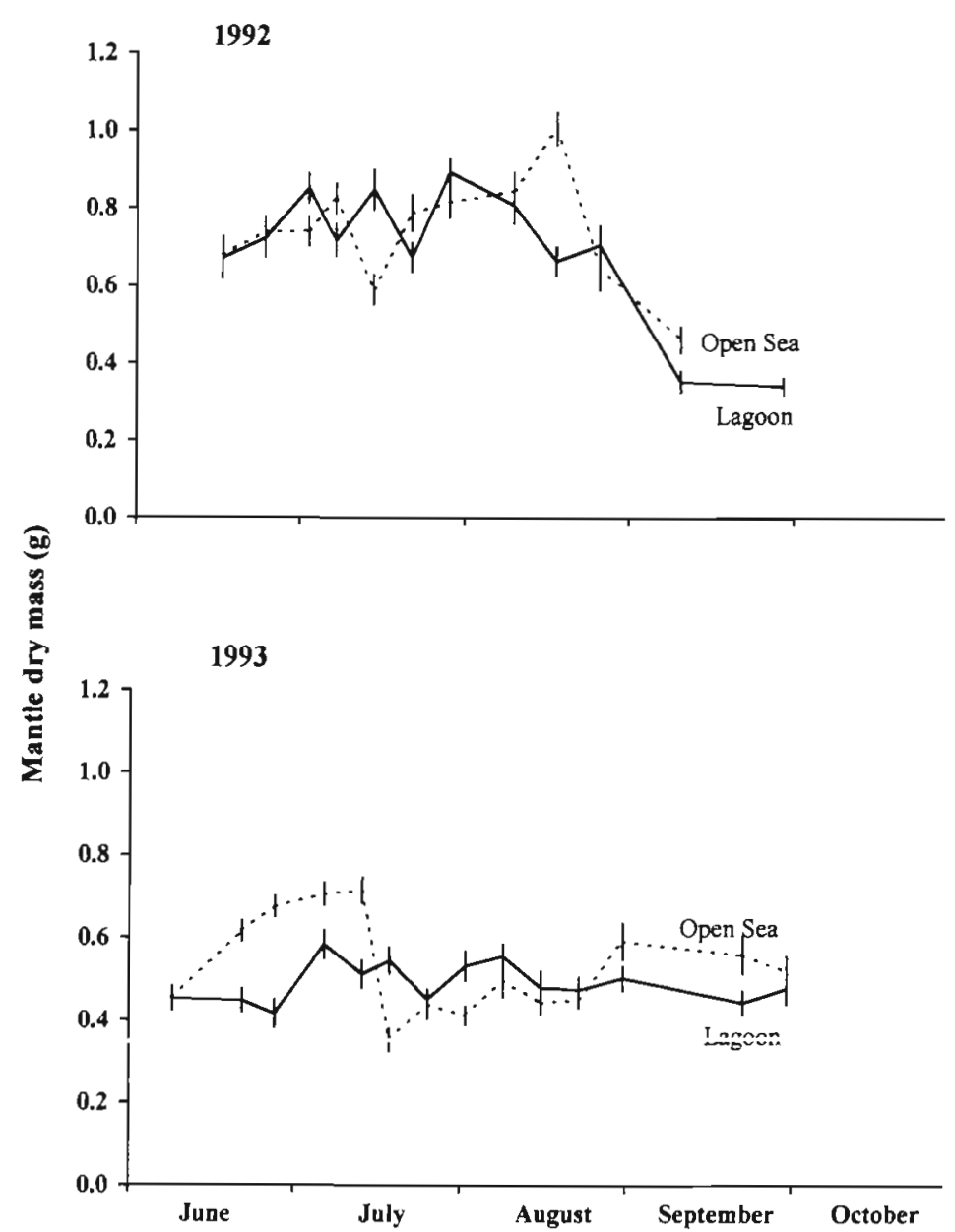

Fig. 5. Mytilus edulis. Mean dry mass of the mantle of mussels in the lagoon and in the open sea in the Magdalen Islands over the summers of 1992 and 1993. Vertical bars represent standard errors. The lowest mantle mass measured for mussels in the lagoon in 1991 (when summer mortality occurred) was $0.2 \mathrm{~g}$ 


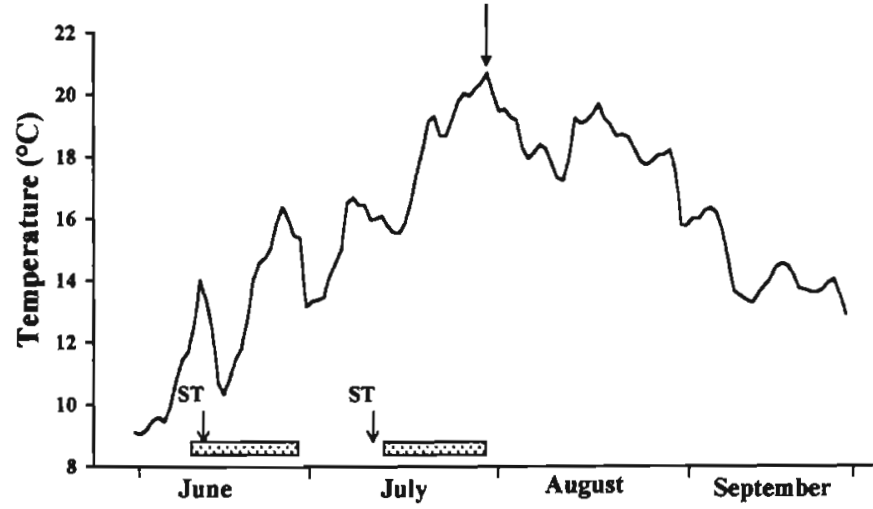

Fig. 6. Daily water temperature in the lagoon in 1991. Periods of spawning are indicated by the horizontal bars. Spring tides (ST) are also indicated. The arrow shows the onset of summer mortality

\section{Environmental conditions}

In 1991, the first spawning in the lagoon occurred during a period of spring tides and as water temperature rapidly increased from 10.3 to $16.4^{\circ} \mathrm{C}$ (Fig. 6), and the second spawning occurred after a period of spring tides and as water temperature increased from 15.6 to $20.7^{\circ} \mathrm{C}$. The summer mortality began during the warmest period of the year when temperatures were over $20^{\circ} \mathrm{C}$. However, a total of only 1.4 day-degrees over $20^{\circ} \mathrm{C}$ was registered during the entire summer in the lagoon, and the summer mortality occurred when water temperatures were decreasing from 20 to $13^{\circ} \mathrm{C}$. In 1992 and 1993, temperatures did not exceed $20^{\circ} \mathrm{C}$ in the lagoon.

We did not obtain a temperature record at sea in 1991 as the thermograph had failed. Data gathered at the same site in 1992 and 1993 indicated that daily water temperatures from 15 June to 15 August vary in a pattern similar to that in the lagoon (Fig. $7 \mathrm{~A}_{i} \mathrm{I}=0.91$; $\mathrm{p}<0.0001 ; \mathrm{n}=124$ ) and are generally 4 to $6^{\circ} \mathrm{C}$ cooler. Therefore water temperatures at sea likely did not exceed $15^{\circ} \mathrm{C}$ during the summer of 1991 since the maximum temperature recorded in the lagoon was $20.7^{\circ} \mathrm{C}$. The highest temperature recorded at sea for 1992 and 1993 was $16.1^{\circ} \mathrm{C}$.

Although food availability was not quantified in 1991, chl a and total seston concentrations were measured weekly during the summers of 1992 and 1993. Changes in total particulate matter (TPM) were correlated at both sites (Fig. 7B; $r=0.78, \mathrm{p}<0.0001, \mathrm{n}=26$ ). Weekly TPM values were usually higher in the lagoon

1992

Temperature
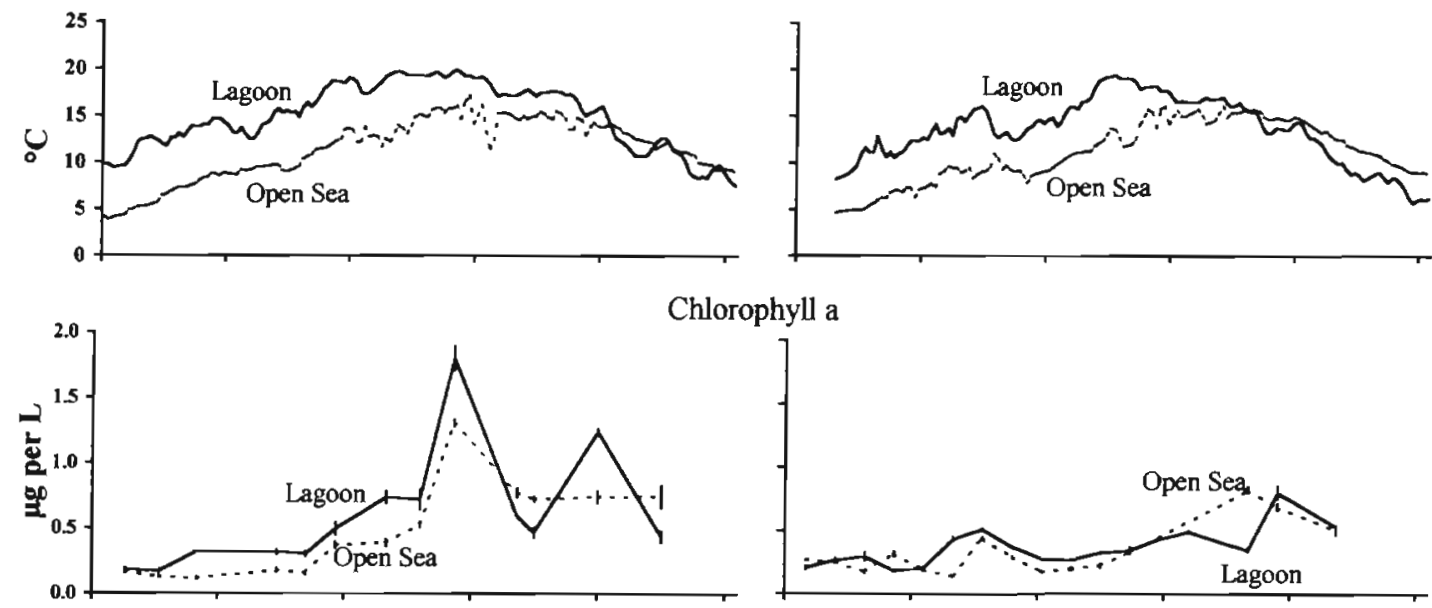

Chlorophyll a
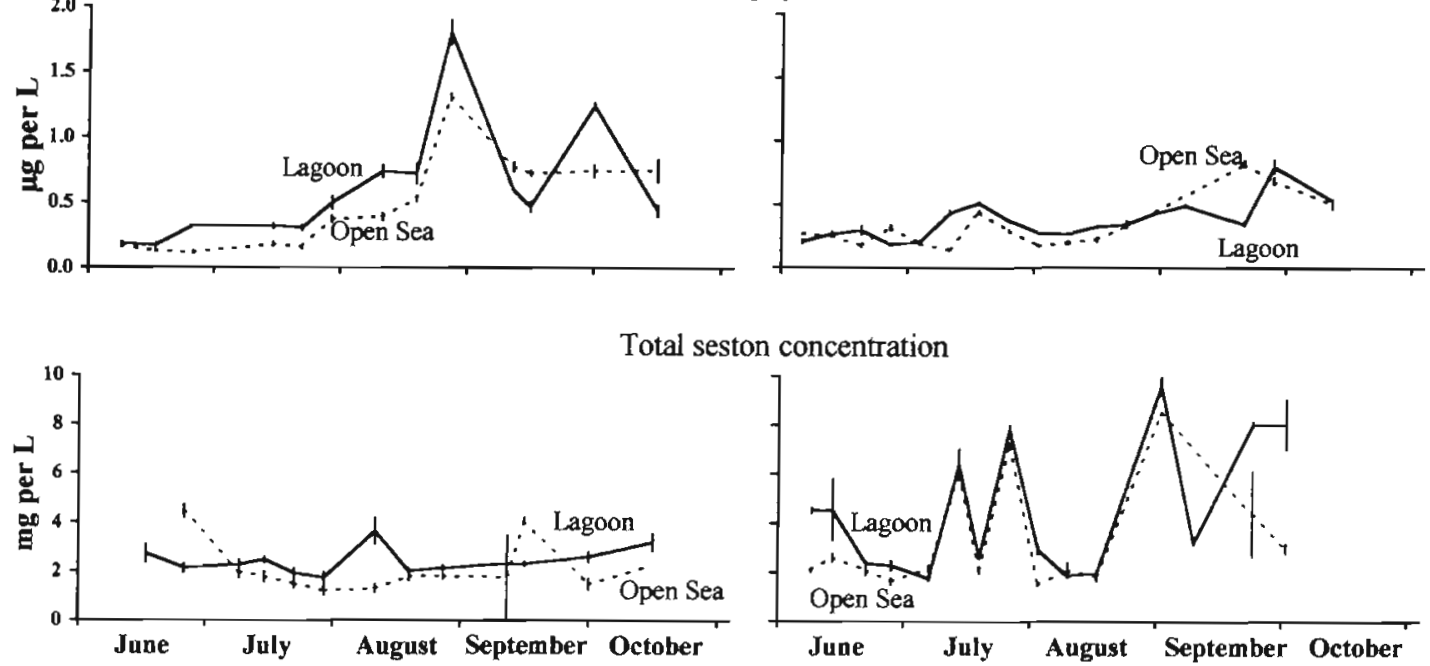

Total seston concentration

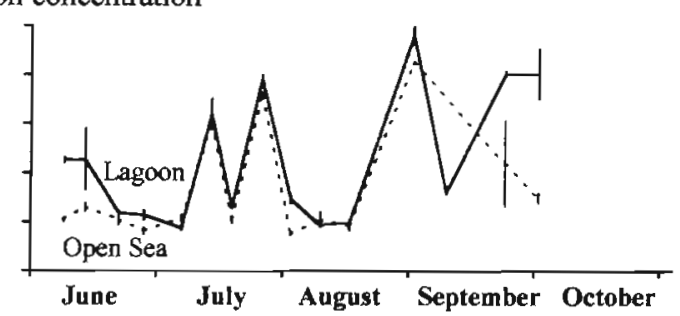

Fig. 7. Environmental conditions in the lagoon and in the open sea in 1992 and 1993: daily temperature, chlorophyll a and total seston concentration. Vertical bars represent standard errors 
than at sea ( $t$-test on differences: mean difference $=0.81 \mathrm{mg} \mathrm{l}^{-1} \pm 0.29 \mathrm{SE}_{,} t_{(26)}=2.80, \mathrm{p}=0.010$ ). Phytoplankton concentrations were also correlated at both sites (Fig. 7C; $\mathrm{r}=0.80, \mathrm{p}<0.0001, \mathrm{n}=29$ ), and no significant difference could be found between sites ( $t$-test on differences: mean difference $=0.06 \mathrm{mg} \mathrm{chl} a$ $\left.1^{-1} \pm 0.04 \mathrm{SE}_{,} t_{(29)}=1.60, p=0.12\right)$. Thus, food concentration was comparable (chl a) or higher (TPM) in the lagoon than at sea

\section{DISCUSSION}

This study provides evidence of a relationship between summer mortality and reproduction of suspension-cultured mussels as previously suggested by Emmett et al. (1987). We studied a mussel stock known to be highly susceptible to summer mortality (Myrand \& Gaudreault 1995). In 1991, we observed 2 major spawnings for mussels held in Great Entry lagoon, and mussels were completely spent at the end of the second spawning. The onset of summer mortality coincided with the end of the second spawning, and about $65 \%$ of the individuals were dead by mid-September 1991. Parallel observations on mussels from the same stock which were held in the open sea showed a major spawning in late June, but no major second spawning in late July and no summer mortality.

At the beginning of the study, the mussels appeared to be ripe and ready to spawn. GVF values were similar to those reported for ripe mussels ( 70 to $90 \%$; Bayne et al. 1978, Lowe et al. 1982, Rodhouse et al. 1984, Salkeld 1995, Danton et al. 1996) and the egg diameter was comparable to reported values for mature eggs $(60$ to $70 \mu \mathrm{m}$; Lubet 1959, Brousseau 1984, Sedano et al. 1995). Similarly, the total dry tissue mass for $55 \mathrm{~mm}$ mussels was in the range of pre-spawning mass of suspension-cultured mussels of similar size in Nova Scotia (Mallet \& Carver 1993). Mantle mass before spawning was similar to values for wild mussels in Atlantic Canada (30 to 50\%; Thompson 1979). Just before we began our study in mid-June, water temperatures had reached the widely reported spawning threshold of 10 to $12^{\circ} \mathrm{C}$ (Bayne 1976, Newell et al. 1991), which may explain why some individuals had already begun to spawn.

The synchrony and the similar reproductive output during the first spawning (late June) at the 2 sites were likely due to the common history of the mussels prior to their transfer to the experimental sites. Although we cannot rule out the possiblity that the initial handling triggered the first spawning, this release of gametes coincided with the first spawning of undisturbed $1 \mathrm{yr}$ old mussels in suspension-culture in the lagoon (authors' unpubl. data). The decrease of protein and lipid content during spawnings reflected their high levels in the gametes (Pieters et al. 1980, Sedano et al. 1995). At both sites, tissue replenishment after the first spawning was synchronous and of similar amplitude The increase in proteins and lipids suggested further maturation and/or production of gametes.

A second major spawning occurred only in mussels held in the lagoon. The follicles were completely empty when this spawning ended. Repeated spawnings in 1 season, separated by short periods of recuperation, often occur in suspension-cultured mussels in the lagoons of the Magdalen Islands (Roussy et al. 1991, Gaudreault \& Myrand 1992). Bouxin (1956) and Lubet (1959) also report similar short intervals prior to a second spawning following an initial partial release of gametes. A massive spawning is followed by a sexual rest (Lubet 1959) during which glycogen is accumulated as an energetic reserve (Bayne 1975, Gabbott 1983). Such a process could explain the rise in the glycogen content of mussels at the onset of the second spawning. This accumulation was likely supported by food resources (increases in phytoplankton concentration and total particulate matter were observed).

The second spawning at sea was small compared to that in the lagoon, even though both groups of mussels had reached the same level of tissue replenishment in mid-July. The high GVF values and large oocyte diameters of the mussels at sea were indicative of mussels ready to spawn. Possibly, the mussels at sea were not exposed to spawning cues because of the depth (13 to $14 \mathrm{~m}$ ) or location (at sea). Nevertheless, they did have a third spawning in late August when water temperatures were only about $10^{\circ} \mathrm{C}$. This spawning was possibly associated with heavy winds $\left(67 \mathrm{~km} \mathrm{~h}^{-1}\right.$ on 20 August compared to velocities $\leq 45 \mathrm{~km} \mathrm{~h}^{-1}$ in mid-July; Environment Canada data from House Harbour airport). Mussels at sea never became completely spent. Mantle mass and total mass remained more or less constant after the replenishment following the first spawning.

A major summer mortality only occurred in the lagoon. The mortality began at the end of the second major spawning, at a point when the reproductive effort of the mussels had been high. To estimate this reproductive effort, we started with the total dry mass of these mussels in November 1990 (780 mg; Myrand \& Gaudreault 1995). The total mean production from November 1990 to mid-September 1991 was $1467 \mathrm{mg}$ (622 mg between November 1990 and the first spawning $+290 \mathrm{mg}$ from early July to just before the second spawning $+55.5 \mathrm{mg}$ after 6 August). Reproductive effort over this period, defined as gamete production over total production, was $31.4 \%$ (a loss of $460 \mathrm{mg}$ in gamete dry mass). However, this value only pertains to the mussels that survived until the end of the experi- 
ment. For mussels which died in August, reproductive effort was more likely about $50.4 \%$ (460 $\mathrm{mg}$ to a total production of $912 \mathrm{mg}$ ). The total energetic content of mussels in the lagoon fell to the lowest level at the end of the second spawning, likely as a consequence of depletion of reserves from spawning and because of low food quality. Food quality, as indicated by the POM:TPM ratio (Bayne et al. 1988), usually decreases in the lagoon during late July to early August (Myrand 1991b, Tremblay et al. 1998c). Numerous studies show that, after spawning, mussels are in poor condition because of depleted reserves and are particularly vulnerable to stressful environmental conditions (Bouxin 1956, Bayne 1975, 1984, Bayne et al. 1978, 1980, Newell \& Thompson 1984).

The high water temperatures in the lagoon in August may have added to the stress of the spent mussels and led to the observed mortalities. Water temperatures over $20^{\circ} \mathrm{C}$ are considered as stressful for mussels (Widdows 1973), and high temperatures are often associated with summer mortalities (Freeman \& Dickie 1979, Mallet 1991, Sephton 1991). Temperatures in the lagoon attained maximal values during the second spawning and were above $20^{\circ} \mathrm{C}$ when mortalities began. However, a total of only 1.4 day-degrees over $20^{\circ} \mathrm{C}$ were cumulated during this period. Stressful temperatures were identified as the major factor explaining summer mortalities of mussels in Maine, as mortality increased at sites where water temperature had been above $20^{\circ} \mathrm{C}$ for varying periods of time (Incze et al. 1980). Most mortalities in our study occurred as water temperatures were declining as observed in Maine (Incze et al. 1980). In early August, metabolic rates of mussels from our experimental stock (susceptible to summer mortality) have higher $Q_{10}$ values at high temperatures $\left(20\right.$ to $\left.25^{\circ} \mathrm{C}\right)$ than those of mussels from a resistant stock (Tremblay et al. 1998a). The ensuing increase in metabolic rate together with a poorer food quality may have reduced the scope for growth of the susceptible mussels (Tremblay et al. 1998c). The high mortalities in our study occurred during the usual period of summer mortality in the Magdalen Islands, a period of peak water temperatures (Myrand 1991a, Myrand \& Gaudreault 1995).

Mortalities in the lagoon were recorded until the end the experiment in mid-September even though the rapid growth of tissues and shell and the increase in glycogen content in late August suggested that the condition of the mussels had improved. Taylor et al. (1992) also observed that suspension-cultured mussels from the Canadian west coast suffered a $50 \%$ mortality between June and August even though their energetic content was improving (higher carbohydrate content in August than in June). We suspect that in spite of these increases, the susceptible mussels still had insufficient reserves to cope with the stressful conditions. Their mantle mass (highly correlated with total tissue mass) was much lower than that observed for mussels in 1992 and 1993 when no summer mortalities occurred. In the lagoon in 1991, an important pulse of summer mortality associated with a halt in shell growth and a decrease in glycogen content occurred in mid-August. Tremblay et al. (1998c) report that the mussels in the lagoon seem to be in poor condition during this period as their scope for growth was negative and the O:N ratio low. Mortalities in our study were not likely caused by disease as no signs of pathogens were found in 56 of the slides used to quantify GVF (pers. comm., Dr Sharon McGladdery, Department of Fisheries and Oceans, Moncton, Canada). Also, other studies on the Atlantic and Pacific coasts of Canada could not link summer mortality to pathogens (Jamieson 1991, Mallet 1991, Sephton et al. 1993).

Our observations suggest that this susceptible stock of mussels from the Magdalen Islands (a more homozygous stock with higher maintenance metabolism during certain periods in summer) pays a survival reproductive cost when a major spawning coincides with a period of stressful environmental conditions. Life history theory indicates that trade-offs must be made when 2 components in an organism's life cycle compete for limited resources. One trade-off is between reproduction and longevity or growth, as energy needed for maintenance and growth is diverted to reproduction (Bell 1980). The reduction in future reproductive capacity caused by a decrease in survival or growth in exchange for increased current reproductive effort is called 'reproductive cost' (Reznick 1985). Reproductive cost is often measured in terms of lower survival of reproducers (Calow 1973, Tallamy \& Denno 1982, Lemckert \& Shine 1993, Boyd et al. 1995, Jacobsen et al. 1995, Luiselli et al. 1996) and is called 'survival reproductive cost' (Bell 1980). As indicated by Roff (1992), it is hard to imagine that reproduction does not deplete the resources of an organism, thereby making it more prone to stress-related sources of mortality. This implies that reproductive cost should increase when conditions become stressful, and conversely decrease under favorable conditions (Browne 1982, Reznick 1985, Roff 1992, Stearns 1992).

As no summer mortalities were observed after the first spawning in the lagoon or after the various spawnings in the open sea, the associated reproductive cost was probably not sufficiently high to cause death. These were only partial releases of gametes during periods when conditions were not stressful (cool water temperatures). Similarly an absence of complete spawnings was associated with a lack of summer mortalities during monitoring of the same stock in 1992 
and 1993. Further, temperature did not exceed $20^{\circ} \mathrm{C}$ in the lagoon during these $2 \mathrm{yr}$. Thus, the summer mortality seemed to have happened only when complete spawning occurred during a period of stressful environmental conditions. Our study supports the suggestion by Bower (1989) and Jamieson (1989) that summer mortalities can be prevented or reduced by transferring mussels to cooler waters in the open sea.

Acknowledgements. We would like to thank all the technical staff of the Station Technologique Maricole des Îles-de-laMadeleine whose full collaboration greatly contributed to the success of this project. We are also grateful to Mr Mario Cyr. who kindly provided us with mussels for this study. Ms Andree Gendron and her technical staff from the MAPAQ Laboratoire de chimie in Gaspé did a great job quantifying the mussels' energetic components. Also, we would like to thank Mr Michel Desbiens and his technical staff from the MAPAQ Laboratoire de microbiologie in Gaspé, who did numerous histological slides. The other slides were prepared by Laboratoires Bio-Recherches Ltée in Senneville. Mr JeanSébastien Brien and $\mathrm{Mr}$ Gaétan Daigle from the Centre de Consultation Statistique de l'Université Laval provided invaluable statistical advice. Finally, we greatly appreciated the valuable comments on this paper from Drs Jacques Larochelle, Julian Dodson, Bruce MacDonald, Jeremy McNeil and Réjean Tremblay.

\section{LITERATURE CITED}

Bayne BL (1975) Reproduction in bivalve molluscs under environmental stress. In: Vernberg FJ (ed) Physiological ecology of estuarine organisms. Univ South Carolina Press, Columbia, p 259-277

Bayne BL (1976) The biology of mussel larvae. In: Bayne BL (ed) Marine mussels: their ecology and physiology. Cambridge University Press, Cambridge, p 81-120

Bayne BL (1984) Aspects of reproductive behaviour within species of bivalve molluscs. In: Engels W (ed) Advances in invertebrate reproduction, Vol 3. Elsevier, Amsterdam, p 357-366

Bayne BL, Holland DL, Moore MN, Lowe DM, Widdows J (1978) Further studies on the effects of stress in the adult on the eggs of Mytilus edulis. J Mar Biol Assoc UK 58: $825-841$

Bayne BL, Brown DA, Harrisson F, Yevich PP (1980) Mussel health. In: Goldberg ED (ed) The international mussel health. US National Academy of Science, Washington, DC, p 163-235

Bayne BL, Salkeld PN, Worrall CM (1983) Reproductive effort and value in different populations of the marine mussel, Mytilus edulis L. Oecologia 59:18-26

Bayne BL, Hawkins AJS, Navarro E (1988) Feeding and digestion in suspension-feeding bivalve molluscs: the relevance of physiological compensations. Am Zool 28: $147-159$

Beaumont AR, Zouros E (1991) Genetics of scallops. In: Shumway SE (ed) Scallops: biology, ecology and aquaculture. Developments in Aquaculture and Fisheries Science, No. 21. Elsevier, Amsterdam, p 585-624

Bell G (1980) The costs of reproduction and their consequences. Am Nat 116:45-76

Bligh EG, Dyer WJ (1959) A rapid method of total lipid extrac- tion and purification. Can J Biochem Physiol 37:911-917 Borsa P, Jousselin Y, Delay B (1992) Relationships between allozymic heterozygosity, body size, and survival to natural anoxic stress in the palourde Ruditapes decussatus L. (Bivalvia: Veneridae). J Exp Mar Biol Ecol 155:169-181

Bouxin $\mathrm{H}$ (1956) Observations sur le frai de Mytilus edulis var. galloprovincialis ( $\mathrm{Lmk}$ ), dates précises de frai et facteurs provoquant l'émission de produits génitaux. Conseil international pour l'exploration de la Mer (CIEM), Copenhague, Shellfish Committee 36:43-46

Bower SM (1989) The summer mortality syndrome and haemocytic neoplasia in mussels (Mytilus edulis) from British Columbia. Can Tech Rep Fish Aquat Sci 1703:1-65

Boyd IL, Croxall JP, Lunn NJ, Reid K (1995) Population demography of Antarctic fur seals: the costs of reproduction and implications for Life-histories. J Anim Ecol 64: 505-518

Briarty LG (1975) Stereology: methods for quantitative light and electron microscopy. Sci Prog, Lond 62:1-32

Brousseau DJ (1984) Aspects of reproduction of the blue mussel, Mytilus edulis (Pelecypoda: Mytilidae) in Long Island Sound. Fish Bull (Wash DC) 81:733-739

Browne RA (1982) The costs of reproduction in brine shrimp. Ecology 63:43-47

Calow P (1973) The relationship between fecundity, phenology and longevity: a systems approach. Am Nat 107: 559-574

Crisp DJ (1984) Energy flow measurement. In: Holme NA, McIntyre AD (eds) Methods for the study of marine benthos. IBP Handbook No. 16, Blackwell Scientific Publ, Oxford, p 197-279

Danton E, Kiyomoto M, Komaru A, Wada KT, Awaji M, Mathieu $M$ (1996) Comparative analysis of storage tissue and insulin-like neurosecretion in diploid and triploid mussels Mytilus galloprovincialis LMK in relation to their gametogenesis cycle. Invertebr Reprod Devel 29:37-46

Davidson LA, Worms J (1989) Stages of gonad development in the sea scallop Placopecten magellanicus (Gmelin) based on both macroscopic and microscopic observation of the gametogenic cycle. Can Tech Rep Fish Aquat Sci 1689:1-20

Diehl WJ, Gaffney PM, Koehn RK (1986) Physiological and genetic aspects of growth in the mussel Mytilus edulis. I. Oxygen consumption, growth and weight loss. Physiol Zool 59:201-211

Dickie LM, Boudreau PR, Freeman KR (1984) Influences of stock and site on growth and mortality in the blue mussel (Mytilus edulis). Can J Fish Aquat Sci 41:134-140

Diehl WJ, Koehn RK (1985) Multiple-locus heterozygosity, mortality and growth in a cohort of Mytilus edulis. Mar Biol 88:265-272

Emmett BK (1988) Proceedings of the British Columbia Mussel Culture Workshop. Archipelago Marine Research, Victoria

Emmett BK. Thompson K. Popham JD (1987) The reproductive and energy storage cycles of 2 populations of Mytilus edulis (Linné) from British Columbia. J Shellfish Res $6: 29-36$

Freeman KR, Dickie LM (1979) Growth and mortality of the blue mussels (Mytilus edulis) in relation to environmental indexing. J Fish Res Board Can 35:1238-1249

Freere RH (1967) Stereologic techniques in microscopy. J R Microsc Soc 87:25-34

Fuentes J, Reyero I, Zapata C, Alvarez G (1992) Influence of stock and culture site on growth and mortality of mussels (Mytilus galloprovincialis LMK) in Galicia, Spain. Aquaculture 105:131-142 
Gabbott PA (1983) Developmental and seasonal metabolic activities in marine molluscs. In: Hochachka PW (ed) The Mollusca, Vol 2. Environmental biochemistry and physiology. Academic Press, New York, p 165-217

Gaudreault J, Myrand B (1992) Caractéristiques de la ponte, de la vie larvaire et de la fixation des moules sur les collecteurs dans la lagune de Havre-aux-Maisons. Ministère de l'agriculture, des pêcheries et de l'alimentation du Québec-Pêcheries, Direction de la recherche scientifique et technique. Gaspé, Document de recherche 92/15,1-15

Gendron A, Rioux JA (1994) Composition chimique de moules (Mytilus edulis) d'élevage de 1 an et 2 ans aux lles-dela-Madeleine durant l'été et l'automne 1993. Ministère de l'agriculture, des pêcheries et de l'alimentation du Québec-Pêcheries, Direction de la recherche scientifique et technique. Gaspé, Rapport d'analyse 94/08,1-42

Gentili HR, Beaumont AR (1988) Environmental stress, heterozygosity, and growth rate in Mytilus edulis L. J Exp Mar Biol Ecol 120:145-154

Goodman LA (1960) On the exact variance of products. J Am Statist Assoc 55:708-713

Gosling EM (1992) Genetics of Mytilus. In: Gosling EM (ed) The mussel Mytilus: ecology, physiology, genetics and culture. Developments in Aquaculture and Fisheries Science, No. 25. Elsevier, Amsterdam, p 309-382

Grant A. Tyler PA. (1983) The analysis of data in studies of invertebrate reproduction. II. The analysis of oocyte size/frequency data, and comparison of different types of data. Int J Invertebr Reprod 6:259-269

Griffiths CL, Griffiths RJ (1987) Bivalvia. In: Pandain TJ, Vernberg FJ (eds) Animal energetics, Vol 2. Academic Press, New York, p 1-89

Hawkins AJS, Bayne BL (1992) Physiological interrelations and the regulation of production. In: Gosling EM (ed) The mussel Mytilus: ecology, physiology, genetics and culture. Developments in Aquaculture and Fisheries Science, No 25. Elsevier, Amsterdam, p 171-222

Hawkins AJS, Bayne BL, Day AJ (1986) Protein turnover physiological energetics and heterozygosity in the blue mussel, Mytilus edulis: the basis of variable, age-specific growth. Proc R Soc Lond B Biol Sci 229:161-176

Hawkins AJS, Rusin J, Bayne BL, Day AJ (1989) The metabolic/physiological basis of genotype-dependent mortality during copper exposure in Mytilus edulis. Mar Environ Res 28:253-257

Hilbish TJ, Zimmerman KM (1988) Genetic and nutritional control of the gametogenic cycle in Mytilus edulis. Mar Biol 98:223-228

Incze LS, Lutz RA, Watling L (1980) Relationships between effects of environmental temperature and seston on growth and mortality of Mytilus edulis in a temperate northern estuary. Mar Biol 57:147-156

Jacobsen KO, Erikstad KE, Saether BE (1995) An experimental study of the costs of reproduction in the Kittiwake Rissa tridactyla. Ecology 76:1636-1643

Jamieson GS (1989). Growth, reproduction, and longevity of blue mussels (Mytilus edulis): implications to northeastern Pacific mussel culture. J World Aquacult Soc 20:94-100

Jamieson GS (1991) Blue mussel (Mytilus edulis) mortality in British Columbia. In: Atelier de travail sur la mortalité estivale des moules aux Iles-de-la-Madeleine. Conseil de l'aquiculture et des pêches du Québec, Québec, p 139-149

Kautsky N (1982) Quantitative studies on gonad cycle, fecundity, reproductive output and recruitment in a Baltic Mytilus edulis population. Mar Biol 68:143-160

Koehn RK, Bayne BL (1989) Towards a physiological and genetical understanding of the energetics of the stress response. Biol J Linn Soc 37:157-171

Landwer AJ (1994) Manipulation of egg production reveals casts of reproduction in the tree lizard (Urosaurus ornatus). Oecologia 100:243-249

Lemckert FI, Shine R (1993) Costs of reproduction in a population of the frog Crinia signifera (Anura, Myobatrachidae) from southeastern Australia. J Herpetol 27:420-425

Lowe DM, Moore MN, Bayne BL (1982) Aspects of gametogenesis in the marine mussel Mytilus edulis L. J Mar Biol Assoc UK 62:133-145

Lubet p (1959) Recherches sur le cycle sexuel et l'émission des gamètes chez les mytilidés et les pectinidés. Rev Trav Inst Peches Marit 1959:389-548

Lubet p (1976) Ecophysiologie de la reproduction chez les mollusques lamellibranches. Haliotis 7:49-55

Luiselli L, Capula M, Shine R (1996) Reproductive output, costs of reproduction and ecology of the smooth snake, Coronella austriaca, in the eastern Italian Alps. Oecologia 106: $100-110$

Mallet AL (1991) Natural mortality of blue mussels under cultured conditions. In: Atelier de travail sur la mortalité estivale des moules aux lles-de-la-Madeleine. Conseil de l'aquiculture et des pêches du Québec, Québec, p 159-169

Mallet AL, Carver CAE (1989) Growth, mortality, and secondary production in natural populations of the blue mussel, Mytilus edulis. Can J Fish Aquat Sci 46:1154-1159

Mallet AL, Carver CAE (1993) Temporal production patterns in various size groups of the blue mussel. J Exp Mar Biol Ecol 170:75-90

Mallet AL, Myrand B (1995) The culture of the blue mussel in Atlantic Canada. In: Boghen AD (ed) Cold-water aquaculture in Atlantic Canada, 2nd edn. Canadian Institute for Research and Regional Development, Moncton, p 255-296

Mallet AL, Carver CAE, Coffen SS, Freeman KR (1987) Mortality variations in natural populations of the blue mussel, Mytilus edulis. Can J Fish Aquat Sci 44:1589-1594

Mallet AL, Carver CAE, Freeman KR (1990) Summer mortality of the blue mussel in eastern Canada: spatial, temporal, stock and age variation. Mar Ecol Prog Ser 67:35-42

Mayzaud P, Koutitonski VG, Souchu P, Roy S, Navarro N, Gomez-Reyez E (1992) L'impact de l'activité mytilicole sur la capacité de production du milieu lagunaire des lles-dela-Madeleine. Rapport INRS-Océanologie pour le ministère des Pêches et Océans Canada, mars 1992, Rimouski

Myrand B (1990) Can we increase mussel (Mytilus edulis) production in the Magdalen Islands (Québec, Canada) by better use of local stock-site combinations? Bull Aquacult Assoc Can 90(4):72-74

Myrand B (1991a) Historique et problématique de la mortalité massive aux Iles-de-la-Madeleine. In: Atelier de travail sur la mortalité estivale des moules aux Îles-de-laMadeleine. Conseil de l'aquiculture et des pêches du Québec, Québec, p 9-20

Myrand B (1991b) Conditions environnementales dans les lagunes des Îles-de-la-Madeleine et paramètres biologiques de la moule bleue. In: Atelier de travail su la mortalité estivale des moules aux Îles-de-la-Madeleine. Conseil de l'aquiculture et des pêches du Québec. Québec, p 47-58

Myrand B, Gaudreault J (1995) Summer mortality of blue mussels (Mytilus edulis Linneaus, 1758) in the Magdalen Islands (southern Gulf of St Lawrence, Canada). J Shellfish Res 14:395-404

Newell CR, Hidu H, McAlice BJ, Podniesinski G, Short F, 
Kindblom L (1991) Recruitment and commercial seed procurement of the blue mussel Mytilus edulis in Maine. $J$ World Aquacult Soc 22:134-152

Newell RIE, Thompson RJ (1984) Reduced clearance rates associated with spawning in the mussel, Mytilus edulis (L.) (Bivalvia, Mytilidae). Mar Biol Lett 5:21-34

Peterson IK (1980) Sources of variation in feeding and respiration rates of Mytilus edulis. MSc thesis, Dalhousie University, Halifax, Canada

Pieters H, Kluytmans JH, Zandee DI, Cadee GC (1980) Tissue composition and reproduction of Mytilus edulis in relation to food availability. Neth J Sea Res 14:349-361

Poirier L, Myrand B (1982) Élevage de la moule bleue, Mytilus edulis, dans les lagunes des îles-de-la-Madeleine (Québec). Trav Pech Que 49:1-64

Reznick D (1985) Costs of reproduction: an evaluation of the empirical evidences. Oikos 44:257-267

Robledo JAF, Santarem MM, Gonzalez P, Figueras A (1995) Seasonal variations in the biochemical composition of the serum of Mytilus galloprovincialis Lmk and its relationship to the reproductive cycle and parasitic load. Aquaculture 133:311-322

Rodhouse PG, Roden CM, Burnell GM, Hensey MP, McMahon T, Ottway B, Ryan TH (1984) Food resource, gametogenesis and growth of Mytilus edulis on the shore and in suspended culture: Killary Harbour, Ireland. J Mar Biol Assoc UK 64:513-529

Rodhouse PG, McDonald JH, Newell RIE, Koehn RK (1986) Gamete production, somatic growth and multiple-locus enzyme heterozygosity in Mytilus edulis. Mar Biol 90:209-214

Roff DA (1992) The evolution of life histories. Chapman and Hall, London

Roussy M, Myrand B, Gaudreault J (1991) Approche suédoise de la mytiliculture appliquée aux Îles-de-la-Madeleine: suivi larvaire et production de moules commerciales sur différents types de collecteurs, saison 1989. Ministère de l'agriculture, des pêcheries et de l'alimentation du Québec-Pêcheries, Direction de la recherche scientifique et technique. Gaspé, Document de recherche 91/05,1-64

Salkeld PN (1995) Aspects of reproduction associated with the use of a segmented regression to describe the relationship between body weight and shell length of Mytilus edulis. Mar Ecol Prog Ser 124:117-128

SAS Institute (1982) SAS users'guide: Statistics. SAS Institute Inc, Cary, NC

Scott TM, Koehn RK (1990) The effect of environmental stress on the relationship of heterozygosity to growth rate in the coot calm Mulinia leteralis (Say). J Exp Mar Biol Ecol 135:109-116

Sedano FJ, Rodriguez JL, Ruiz C, Garcia-Martin LO, Sanchez

Editorial responsibility: Otto Kinne (Editor),

Oldendorf/Luhe, Germany
JL (1995) Biochemical composition and fertilization in the eggs of Mytilus galloprovincialis (Lamarck). J Exp Mar Biol Ecol 192:75-86

Seed R, Suchanek TH (1992) Population and community ecology of Mytilus. In: Gosling EM (ed) The mussel Mytilus: ecology, physiology, genetics and culture. Developments in aquaculture and fisheries science, No. 25. Elsevier, Amsterdam, p 87-169

Sephton TW (1991) Summer mortality of cultured mussels in Prince Edward Island, Canada. In: Atelier de travail sur la mortalité estivale des moules aux İles-de-la-Madeleine. Conseil de l'aquiculture et des pêches du Québec, Québec, p 151-157

Sephton TW, Landry T, Ryan CF (1993) Summer mortality of cultured blue mussels in Prince Edward Island, Canada. Bull Aquacult Assoc Can 93(4):59-61

Stearns S (1992) Evolution of life histories. Oxford University Press, Oxford

Tallamy DW, Denno RF (1982) Life history trade-offs in Gargaphia solani (Hemiptera: Tinidae): the cost of reproduction. Ecology 63:616-620

Taylor BE, Jamieson G, Carefoot TH (1992) Mussel culture in British Columbia: the influence of salmon farms on growth of Mytilus edulis. Aquaculture 108:51-66

Thompson RJ (1979) Fecundity and reproductive effort in the blue mussel (Mytilus edulis), the sea urchin (Strongylocentrotus droebachiensis\}, and the snow crab (Chionocetes ophilio) from populations in Nova Scotia and Newfoundland. J Fish Res Board Can 36:955-964

Thompson RJ (1991) Mortality in mussels: a physiological perspective. In: Atelier de travail sur la mortalité estivale des moules aux Îles-de-la-Madeleine. Conseil de l'aquiculture et des pèches du Québec, Québec, p 171-176

Tremblay R, Myrand B, Guderley H (1998a) Thermal sensitivity of organismal and mitochondrial oxygen consumption in relation to susceptibility of blue mussels, Mytilus edulis (L.), to summer mortality. J Shellfish Res $17: 141-152$

Tremblay R, Myrand B, Sévigny JM (1998b) Genetic characterization of wild and suspension-cultured blue mussels (Mytilus edulis Linneaus, 1758), in the Magdalen Islands (southern Gulf of St. Lawrence, Canada). J Shellfish Res 17:1191-1202

Tremblay R, Myrand B, Sévigny JM, Guderley $H$ (1998c) Bioenergetic and genetic parameters in relation to susceptibility of blue mussels, Mytilus edulis (L) to summer mortality. J Exp Mar Biol Ecol $221: 27-58$

Van Hendel E (1965) Estimation of glycogen in small amounts of tissue. Anal Biochem 11:256-265

Widdows J (1973) The effects of temperature on the metabolism and activity of Mytilus edulis. Neth $J$ Sea Res $7: 387-398$

Submitted: September 21, 1998; Accepted: October 26, 1999 Proofs received from author(s): April 5, 2000 